\title{
An experimental study of REE and HFSE partitioning between low-Ca pyroxene and parental melts of Martian shergottite meteorites
}

\author{
JAKE ACQUADRO $^{1}$ AND YAN LIANG ${ }^{1}$ \\ ${ }^{1}$ Dept. of Earth, Environ. and Planet. Sci., Brown University, \\ Providence, RI 02912, USA (yan_liang@brown.edu)
}

Abundances of REE in low-Ca pyroxene in shergottites have been widely used to infer magmatic processes and parental melt compositions of shergottites. To accurately determine the parental melt composition, one needs pyroxene-melt trace element partition coefficients which depend on temperature and pyroxene and melt compositions. Partition coefficients of REE in low-Ca pyroxene that have been widely used in the Martian meteorite literature were determined 30 years ago $[1,2]$. Given the extrapolated nature of some of the earlier partition coefficients, the ever growing trace element data for Martian meteorites, and recent advances in quantifying REE and HFSE partitioning in pyroxenes, it is time to update the REE and HFSE partitioning data and model for the Martian meteorites. In order to better constrain the range of partition coefficients for REE and HFSE between low-Ca pyroxene and shergottite melt, we conducted high pressure (1 $\mathrm{GPa})$ and high temperature $\left(1150-1235^{\circ} \mathrm{C}\right)$ piston-cylinder experiments in which we grew low-Ca pyroxene [Mg\# 79-83, $1.1-1.8 \mathrm{wt} \%$ $\mathrm{CaO}, 0.7-2.5 \% \mathrm{Al}_{2} \mathrm{O}_{3}$ ] in equilibrium with shergottite melts [Mg\# 47-65, 9-11\% $\left.\mathrm{CaO}, 8-12 \% \mathrm{Al}_{2} \mathrm{O}_{3}\right]$. In some runs, olivine, high-Ca pyroxene, and/or plagioclase were also present. We measured the concentrations of REE and HFSE in coexisting minerals and melt using an LA-ICP-MS. Our measured REE partition coefficients for low-Ca pyroxenes to date are up to 6 times lower than values used in the Martian meteorite literature $[1,2]$ and up to 3 times lower than values predicted by the lattice strain model of [3]. We attribute these differences to pyroxene major element composition, temperature, and extrapolated nature of the earlier data or model. The new shergottite-relevant trace element partitioning data allow us to update the parameterized lattice strains models for REE and HFSE partitioning in low-Ca pyroxene (and perhaps olivine and augite as well) over a larger range of pyroxene and melt compositions than previously possible. Applications of the new partitioning model to Martian shergottite meteorites will be presented.

[1] Lundberg et al. (1990) GCA 54, 2535-2547.

[2] McKay et al. (1986) GCA 50, 927-937.

[3] Sun and Liang (2013) GCA 119, 340-358. 